\title{
Balkanologie
}

Balkanologie Revue d'études pluridisciplinaires

Vol. VIII, $n^{\circ} 1$ | 2004

Volume VIII Numéro 1

\section{Zakošek (Nenad), Politički sustav Hrvatske [Le système politique de la Croatie]}

Zagreb: Fakultet Političkih nauka, 2002, 146 pages

Yves Tomić

\section{CpenEdition}

\section{Journals}

Édition électronique

URL : http://journals.openedition.org/balkanologie/2086

DOI : $10.4000 /$ balkanologie.2086

ISSN : 1965-0582

\section{Éditeur}

Association française d'études sur les Balkans (Afebalk)

Édition imprimée

Date de publication : 1 juin 2004

ISSN : 1279-7952

\section{Référence électronique}

Yves Tomić, «Zakošek (Nenad), Politički sustav Hrvatske [Le système politique de la Croatie]»,

Balkanologie [En ligne], Vol. VIII, $n^{\circ} 1$ | 2004, mis en ligne le 21 janvier 2010, consulté le 17 décembre

2020. URL : http://journals.openedition.org/balkanologie/2086; DOI : https://doi.org/10.4000/

balkanologie. 2086

Ce document a été généré automatiquement le 17 décembre 2020.

(C) Tous droits réservés 


\title{
Zakošek (Nenad), Politički sustav Hrvatske [Le système politique de la Croatie]
}

Zagreb: Fakultet Političkih nauka, 2002, 146 pages

\author{
Yves Tomić
}

\section{RÉFÉRENCE}

Zakošek (Nenad), Politički sustav Hrvatske [Le système politique de la Croatie], Zagreb :

Fakultet Političkih nauka, 2002, 146 p.

1 Modeste (146 p.), cet ouvrage n'en constitue pas moins une excellente synthèse de la vie politique croate des années 90 . L'auteur y analyse le système politique croate : les lois électorales et les élections, le système des partis politiques, le parlement, le président de la république, le gouvernement, les groupes d'intérêts, les médias, la justice. On relèvera en particulier l'analyse du modèle des clivages structurels de Lipset et Rokkan appliqué à la Croatie, ainsi que des modèles de Herbert Kitschelt et de György G. Markus. Écrit clairement, cet ouvrage fournit les éléments essentiels pour appréhender les événements politiques en Croatie entre 1990 et 2000. 